Original Article

\title{
EFFECTS OF EXTRACTS OF STOCHEOSPERMUM MARGINATUM AND ULVA LACTUCA ON THE HAEMATOLOGICAL AND IMMUNOLOGICAL PARAMETERS ON AEROMONAS HYDROPHILA INFECTED CYPRINUS CARPIO
}

\author{
A. MOHAIDEEN ${ }^{*}$, G. THEIVANDRAN ${ }^{2}$ \\ 1PG Department of Zoology, Sadakathullah Appa College, Tirunelveli, ${ }^{2 D e p a r t m e n t ~ o f ~ Z o o l o g y, ~ P T M T M ~ C o l l e g e, ~ K a m u t h i ~}$ \\ Email: mohaideen2020@gmail.com \\ Received: 11 Sep 2021, Revised and Accepted: 14 Nov 2021
}

\begin{abstract}
Objective: Marine algae are the rich source of natural products with pharmacological and biological activities. In the present study the seaweeds Stocheospermum marginatum and Ulva lactuca extracts were used as a immuno stimulants of non-specific immune response in common carp were studied.

Methods: The seaweeds Stocheospermum marginatum and Ulva lactuca chosen for the study and were extracted with ethanol. The fishes common carp (Cyprinus carpio) (weight $10 \pm 5 \mathrm{~g}$ )] were divided into five groups. They were infected with $A$. hydrophila $\left(1.6 \times 10^{4} \mathrm{CFU} /\right.$ fish). The infected fishes were injected with seaweeds extracts $(0.30 \mathrm{mg})$ suspended in saline solution. One group was injected only saline (control) and one group was injected with ciprofloxacin $(0.30 \mathrm{mg})$ (standard) suspended in saline. The experiment was carried out for $28 \mathrm{~d}$. In every seven days interval the fishes were injected with seaweed extract and blood parameters of RBC, WBC, HB, Ht, MCV, MCH, and MCHC were recorded.
\end{abstract}

Results: $\mathrm{RBC}$ was recorded on $28^{\text {th }}$ day in group $3\left(2.86 \pm 0.11 \times 10^{6}\right.$ cells $\left./ \mathrm{mm}^{3}\right)$ followed by group $4\left(2.13 \pm 0.04 \times 10^{6}\right.$ cells $\left./ \mathrm{mm}^{3}\right)$. Similarly the WBC values also increase from initial day to final day.

The phagocytic assay was same on $28^{\text {th }}$ day in group 3 and group $4(58.89 \pm 1.68)$. The lysozyme activity was more in group 3 on $28^{\text {th }}$ day $1285 \pm 90.92$ but the lowest activity recorded in group 4 on $28^{\text {th }}$ day $1205 \pm 34.35$. The respiratory burst activity was higher in group 3 on $28^{\text {th }}$ day $0.184 \pm 0.012$. Overall results group 3 had the best activity when compared to others.

Conclusion: From this study we can understand that the fish injected with seaweed extracts Stocheospermum marginatum and Ulva lactuca seweed as a good immunostimulant. The seaweeds Stoechospermum marginatum had alkaloids, phenol, quinone, saponin, steroid and terpenoid. Ulva lactuca containedalkaloids, sugar, flavenoid, phenol, quinone, steroid and terpenoid. These secondary metabolites were responsible for the immunostumilant activity.

Keywords: Stocheospermum marginatum, Ulva lactuca, Aeromonas hydrophila, Haemotology, Immunostimulant assay

(C) 2022 The Authors. Published by Innovare Academic Sciences Pvt Ltd. This is an open access article under the CC BY license (https://creativecommons.org/licenses/by/4.0/) DOI: https://dx.doi.org/10.22159/ijcpr.2022v14i1.44114 Journal homepage: https://innovareacademics.in/journals/index.php/ijcpr

\section{INTRODUCTION}

The increasing demand for fish and other aquatic food organisms is the main factor behind growing aquatic animal husbandry or aquaculture [1]. Aquaculture is also called 'underwater agriculture' [2]. A. hydrophila is widely distributed in aquatic environments [3]. Aeromonas hydrophila infection causes a serious damage in pond and aquarium culture. The pathogenesis and histopathology of red-sore disease has been extensively studied in common carp (Cyprinus carpio) [4]. Different approaches have been applied by the farmers mainly Chemotherapies are widely used to control and prevent diseases, which have several drawbacks such as environmental risks, development of resistant pathogens and bioaccumulation [5]. Nowadays, several alternative strategies such as immunostimulants, probiotics, green water technique, vaccination and quorum sensing have been introduced in aquaculture to improve fish resistance to pathogen and improve growth performance [6]. Marine algae are source natural products with pharmacological and biological activities [7]. Especially seaweeds are the source of biomedical compounds [8]. Seaweeds are the potential source of antibiotics, antioxidant and antiinflammatory [9]. Some seaweed has bio-active components which affected the germination of some pathogenic bacteria [10]. Seaweeds extracts were used as therapeutic agents, new compounds were present in oceans and have commercial value [11]. Numerous compounds with cytostatic, antiviral and antibacterial activities have been detected in green, brown and red algae [12]. Marine organisms are potential sources of bioactive secondary metabolites with potential for use in the development of new pharmaceutical agents $[13,14]$ Immunostimulant can be administered to fish is by injection [15]. In the present study the seaweeds Stocheospermum marginatum and Ulva lactuca extracts were used as a immuno stimulants of nonspecific immune response in common carp were studied.

\section{MATERIALS AND METHODS}

\section{Collection of fishes}

Common carp (weight $10 \pm 5 \mathrm{~g}$ ) were collected from a local fish farm in Vellanguli Tirunelveli District. The fish were acclimatized in 100 litre tanks (10 fish/tank) and provided with continuous aeration. During the holding period the fish were fed a control feed at $5 \%$ of their body weight, once a day.

\section{Collection of seaweed}

Live samples of the seaweeds were collected by handpicking during low tide from Hare Island in the Gulf of Mannar of Tuticorin coast (08 46' 2.15"N lat; 78 11' 16.05" E long). The seaweeds were identified with the help of Botany expert in our college. After identification the seaweeds were shade dried and powdered.

\section{Preparation of extracts by soxhlet extraction method}

The powdered samples were extracted by using soxhlet apparatus. Ethanol was taken as the solvent for extraction. $25 \mathrm{~g}$ of the sample and $250 \mathrm{ml}$ of the solvent were taken for extraction. The apparatus was run for $4 \mathrm{hr}$ and syrupy extracts were collected. The extract obtained were concentrated using rotary vacuum evaporator. Then the extract was stored in cold storage for further study.

\section{Test for secondary metabolites}

The secondary metabolites like Alkaloids, Anthroquinones, Catachins, Sugar, Glycoside, Coumarin, Flavonoid, Phenol, Quinone, Saponin, Steroid, Terpenoid were tested. 


\section{Infection of fishes}

Bacterial strain, Aeromonas hydrophila (MTCC No1739) was obtained from Microbial Type Culture Collection and Gene Bank (MTCC) Institute of Microbial Technology, Chandigarh, India. After obtaining bacteria, it was cultured in tryptone soya broth (Himedia) for $24 \mathrm{~h}$ at $37^{\circ} \mathrm{C}$. After incubation period, the culture was centrifuged at $800 \mathrm{~g}$ for $15 \mathrm{~min}$ at $4^{\circ} \mathrm{C}$. The packed cells were washed with phosphate buffered saline (PBS; pH 7.2) twice and then the required dose was prepared in PBS. The $\mathrm{LD}_{50}$ value was calculated based on the mortality rate, with the help stat plus software. After the $\mathrm{LD}_{50}$ calculation the standard infection dosage was analysed. The bacterial suspension was prepared to $1.6 \times 10^{4} \mathrm{CFU} / \mathrm{ml}^{-1}$ fish as determined using an infectiual dosage for Aeromonas hydrophila.

\section{Intra peritoneal injection}

After infection the fish were divided into four groups and injected intraperitonially in seven days interval, namely control group (group 1) injected only saline second one was standard group (group 2) injected with $0.30 \mathrm{mg}$ cyprofloxacin suspended in saline and the third and fourth test groups ethanol extracted seaweeds like Stocheospermum marginatum and Ulva lactuca injected at $0.30 \mathrm{mg}$ of each extracts suspended in saline solution (group 3 and group 4) after determining the $\mathrm{LD}_{50}$ values. Then immunological parameters were analyzed for every $7 \mathrm{~d}$ interval. In the experimental period all group of fishes were fed with control diet.

\section{Haematological studies}

\section{a. Blood collection}

Blood sample was collected from fish of each group. The fishes were collected and gently wiped with a dry cloth to remove water. Caudal peduncle was cut with a sharp blade and the blood was collected in a watch glass containing EDTA, an anticoagulant $(6 \%$ Ethylene
Diamine Tetra Acetic Acid). The blood was mixed well with the EDTA solution by using a needle and this sample was used for determining Hematological studies.

Immune response in common carp was studied by analysing various parameters like RBC, WBC, HB, Hematocrit values, $\mathrm{MCV}, \mathrm{MCH}$, MCHC. All these values were determined using a method originally derived by Yokoyama [16] and later on modified by Christensen et al., [17].

\section{b. Immunological assay}

\section{Phagocytic assay}

Phagocytic activity of neutrophils and monocytes in blood was determined as described by Anderson and Siwicki [18]

\section{Lysozyme assay}

Lysozyme activity of blood serum was determined as described by Anderson and Siwicki [18]

\section{NBT assay}

Production of Oxygen radicals from Phagocytes in the blood was measured using Nitrobluetetrazolium (NBT) due as described by Anderson and Siwicki [18].

\section{Data analysis}

Results are expressed as mean \pm SD. The statistical analysis was performed by using one way ANOVA using SPSS package version 19 .

\section{RESULTS}

The seaweeds Stoechospermum marginatum had alkaloids, phenol quinone, saponin, steroid and terpenoid. Ulva lactuca obtained alkaloids, sugar, flavenoid, phenol, quinone, steroid and terpenoid (table 1).

Table 1: Secondary metabolites in ethanolic extracts of seaweeds

\begin{tabular}{llll}
\hline S. No. & Secondary metabolites & Stoechospermum marginatum & Ulva lactuca \\
\hline 1 & Alkaloids & + & - \\
2 & Anthroquinones & - & - \\
3 & Catachins & - & + \\
4 & Sugar & - & - \\
5 & Glycoside & - & - \\
6 & Coumarin & - & + \\
7 & Flavonoid & + & + \\
8 & Phenol & + & + \\
9 & Quinone & + & - \\
10 & Saponin & + & + \\
11 & Steroid & + & + \\
12 & Terpenoid & & + \\
\hline
\end{tabular}

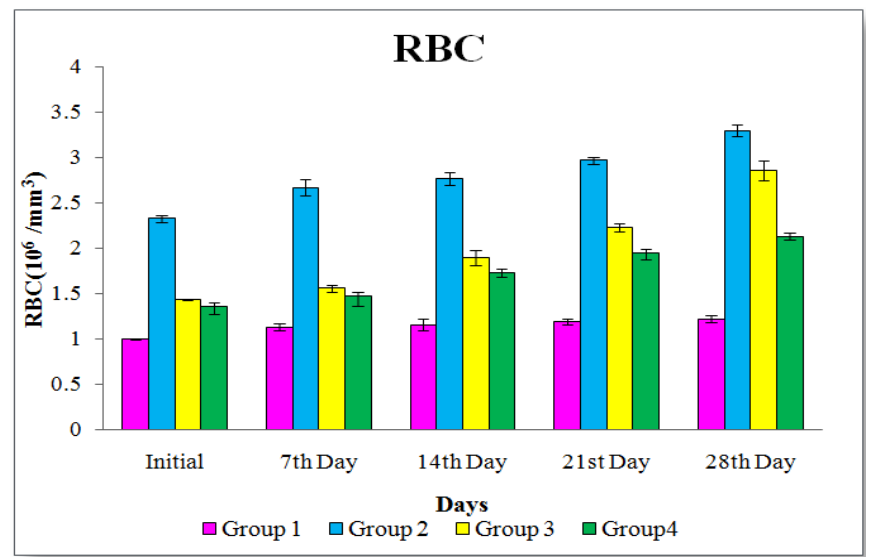

Fig. 1: The RBC value of Cyprinus carpio treated with seaweed extracts

After Aeromonas hydrophila infected fishes were treated with seaweeds extracts there was a gradual increase in the RBC count (fig. 1) from the initial day to the 28th day the highest content of
RBC was recorded on $28^{\text {th }}$ day in group $3\left(2.86 \pm 0.11 \times 10^{6}\right.$ cells $\left./ \mathrm{mm}^{3}\right)$ followed by group $4\left(2.13 \pm 0.04 \times 10^{6}\right.$ cells $\left./ \mathrm{mm}^{3}\right)$. Similarly, the WBC values also increase from initial day to final day. The WBC value of 
group 3 was $20.73 \pm 0.08 \times 10^{3}$ cells $/ \mathrm{mm}^{3}$ and group 4 recorded $19.7 \pm 0.11 \times 10^{3}$ cells $/ \mathrm{mm}^{3}$ on $28^{\text {th }}$ day. When compared to brown and green seaweeds the brown seaweed (group 3) containing Stocheospermum marginatum was more active. The haemoglobin value and hematocrit value also increased from initial day to final day. The maximum haemoglobin was noted in group 4 on $28^{\text {th }}$ day $(5.6 \pm 0.24 \mathrm{~g} \%)$ and minimum haemoglobin observed in group 3 $(5.33 \pm 0.24 \mathrm{~g} \%)$. The highest hematocrit was observed in group $3(19.56 \pm 1.11 \%)$ and $19.33 \pm 0.31 \%$ for group 4 on $28^{\text {th }}$ day. The MCV and $\mathrm{MCH}$ value was decreased from initial to final day. Final day the MCV value of $68.39 \pm 3.15 \mathrm{fl}$ recorded in group 3 and $90.75 \pm 2.07 \mathrm{fl}$ found in group 4. The best activity was found in group 3 and the $\mathrm{MCH}$ value of group 3 was $18.64 \pm 0.40 \mathrm{pg}$ and $26.29 \pm 1.15 \mathrm{pg}$ observed in group 4 on $28^{\text {th }}$ day. The MCHC value also increased from initial day to final day the maximum MCHC was recorded in group 4 on $28^{\text {th }}$ day $28.97 \pm 0.31 \mathrm{~g} / \mathrm{l}$ and minimum recorded $27.25 \pm 1.28 \mathrm{~g} / \mathrm{lin}$ group 3 . The phagocytic assay was same on $28^{\text {th }}$ day in group 3 and group 4 $(58.89 \pm 1.68)$. The lysozyme activity was more in group 3 on $28^{\text {th }}$ day $1285 \pm 90.92$ but the lowest activity recorded in group 4 on $28^{\text {th }}$ day $1205 \pm 34.35$. The respiratory burst activity was higher in group 3 on $28^{\text {th }}$ day $0.184 \pm 0.012$. Overall results group 3 had the best activity when compared to others.

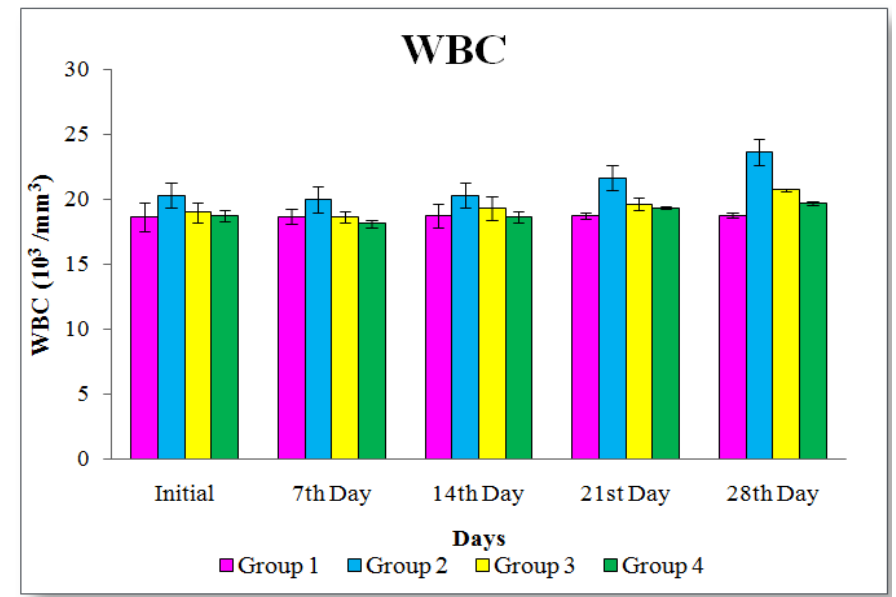

Fig. 2: The WBC value of Cyprinus carpio treated with seaweed extracts

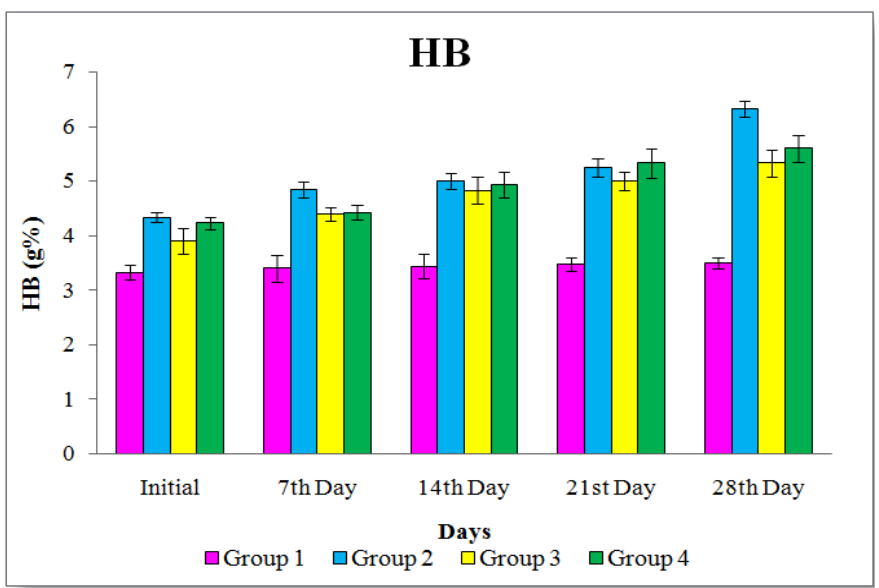

Fig. 3: The Hb value of Cyprinus carpio treated with seaweed extracts

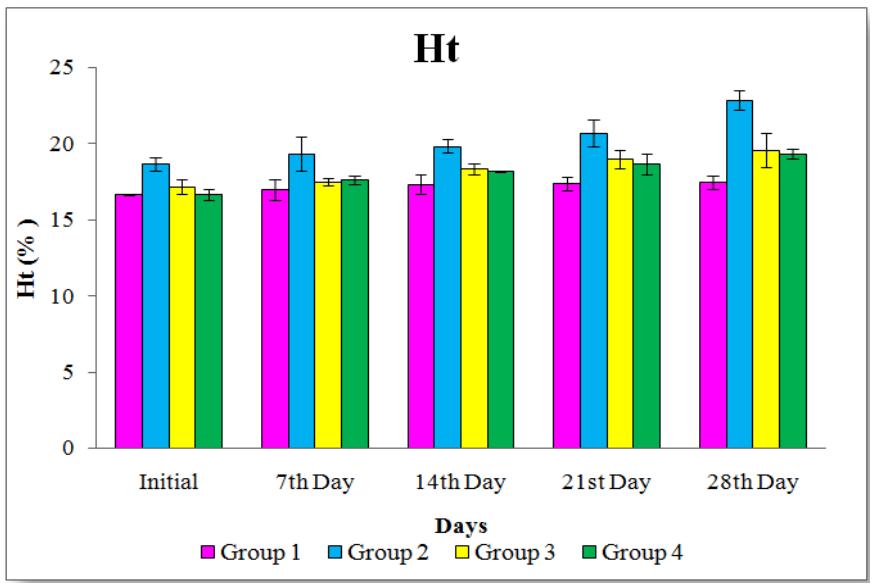

Fig. 4: The Ht value of Cyprinus carpio treated with seaweed extracts 


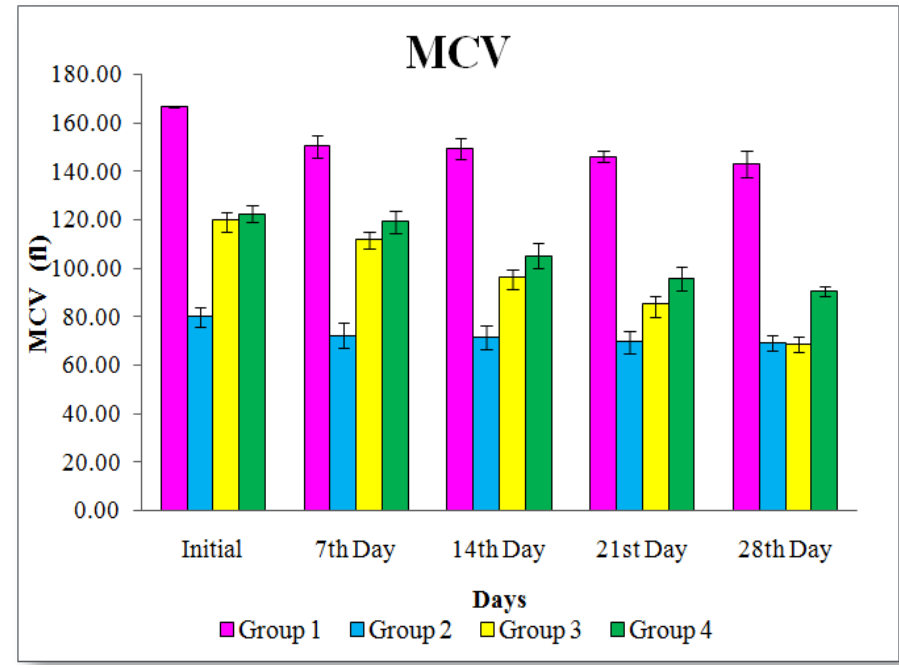

Fig. 5: The MCV value of Cyprinus carpio treated with seaweed extracts

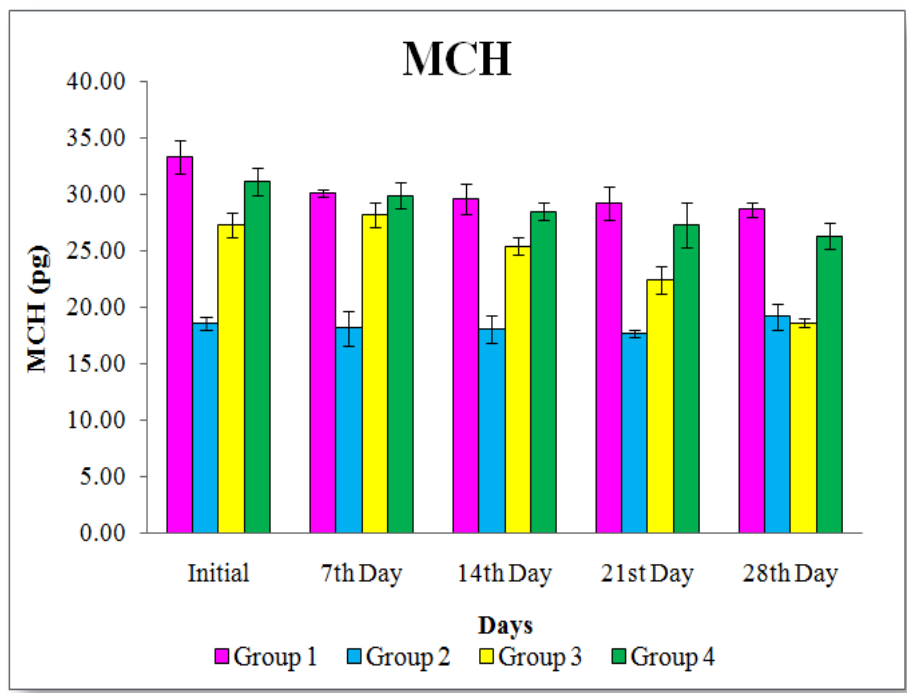

Fig. 6: The MCH value of Cyprinus carpio treated with seaweed extracts

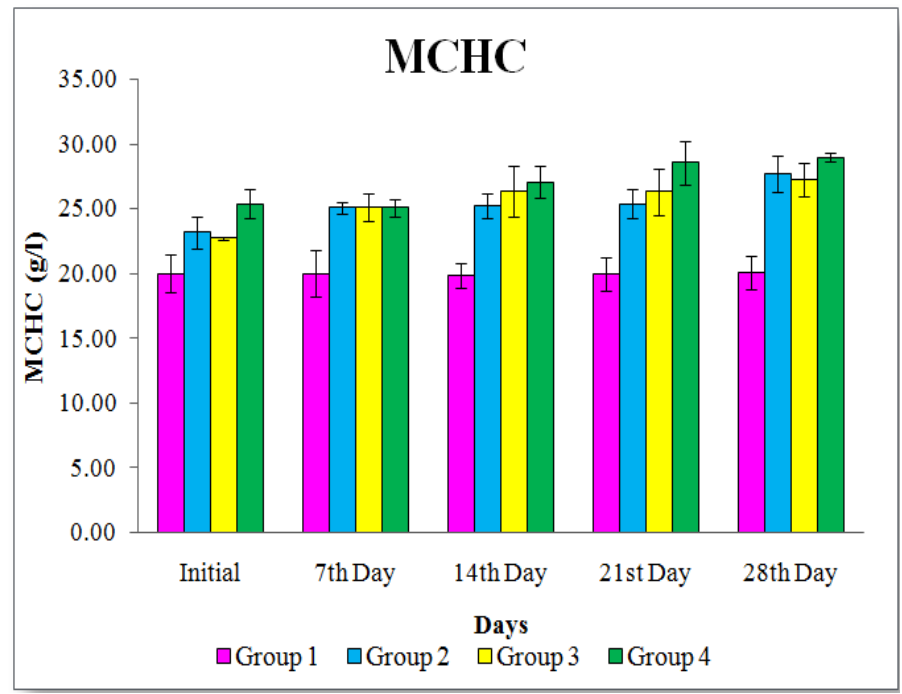

Fig. 7: The MCHC value of Cyprinus carpio treated with seaweed extracts 


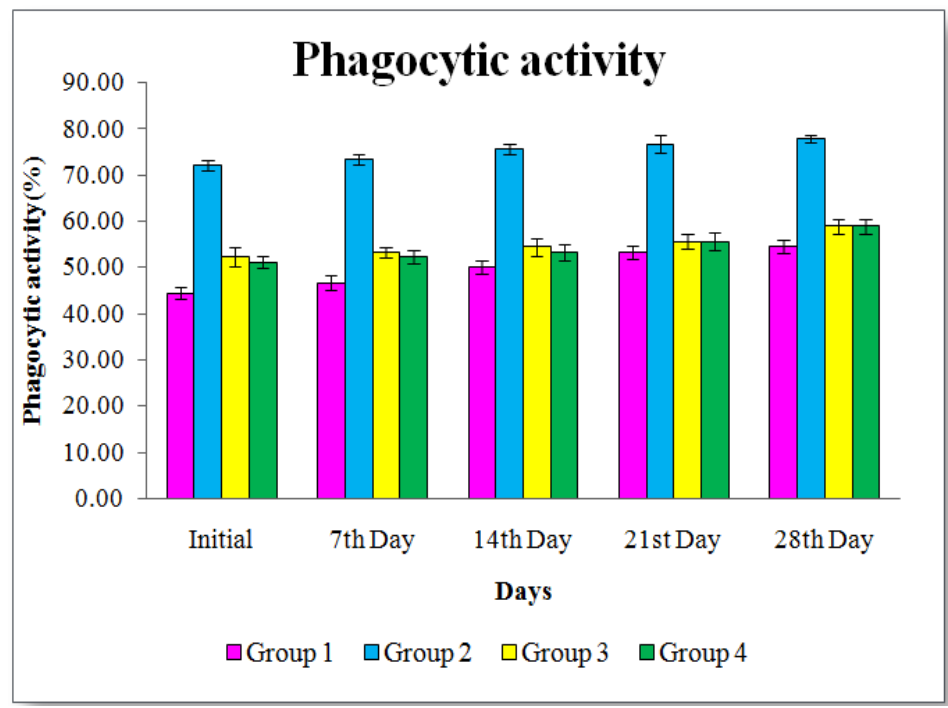

Fig. 8: The phagocytic activity of Cyprinus carpio treated with seaweed extracts

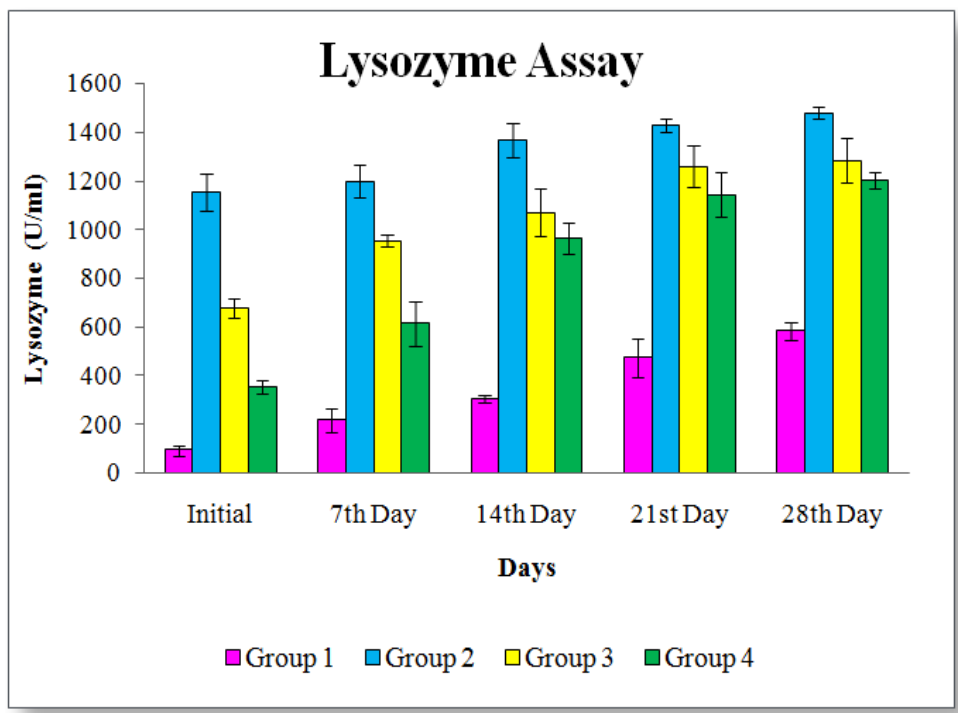

Fig. 9: The lysozyme activity of Cyprinus carpio treated with seaweed extracts

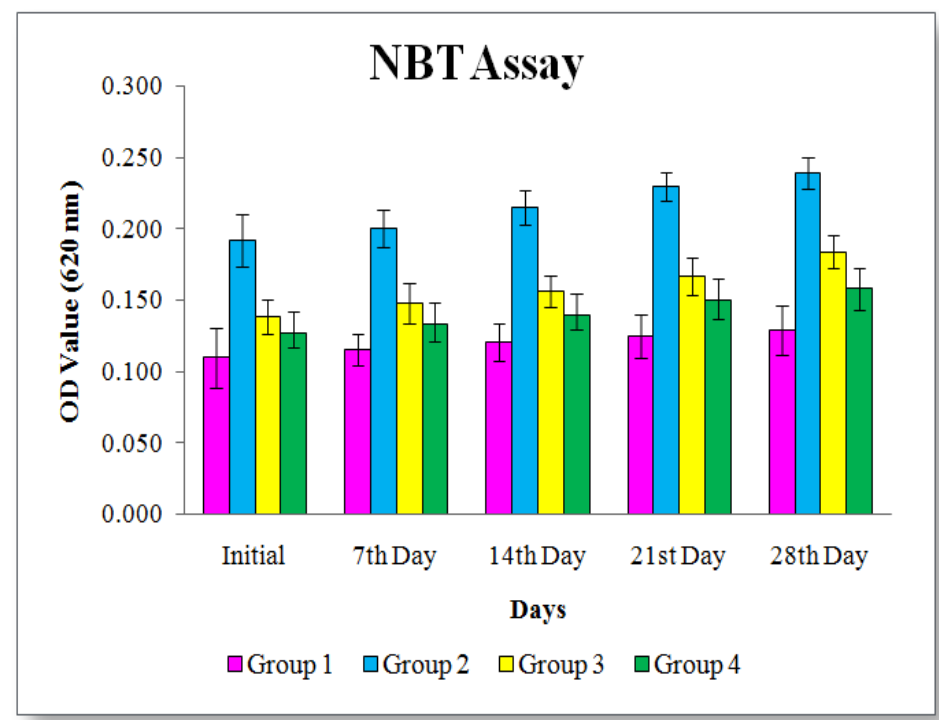

Fig. 10: The NBT Assay of Cyprinus carpio treated with seaweed extracts 


\section{DISCUSSION}

In the present study two types of extracts namely extracts of Stocheosapermum marginatum and Ulva lactua were chosen to study their immunostimulating properties in A. hydrophila infection. The haematological parameters like RBC, WBC, Hb, Ht, MCV, MCH and $\mathrm{MCHC}$ were recorded. The major components of the innate immune system (Non-specific) are macrophages, monocytes, granulocytes and humoral elements [19]. Herbal based immunostimulants are capable of enhancing immune responses and reducing losses from viruses, bacteria and parasitic infections in carp [20]. In the present study, immunostimulant effect of seaweed extract was performed in Cyprinus carpio at the dose of $0.30 \mathrm{mg} / \mathrm{ml}$ through intraperitoneal injection and the immunological parameters were measured at 0 , $7^{\text {th }}, 14^{\text {th }}, 21^{\text {st }}$ and $28^{\text {th }}$ day.

The WBC plays an important role in the immune response of fish particularly in inflammation [21]. The WBC content increased from the initial day to the final day after injection they were higher in both group 4 and group 5 when compared to the control. This corroborates with the total WBC count increase in fish by the different plant extracts 65\% in Cyprinus carpio [22]; 56\% in carp immunized with Ganaderma and Aastrapulus [23]. Thus the total WBC count increase in the fish may be due to an initial sign of nonspecific immune response [24]. They may be enhanced as it is the first line of defense [25].

In fish phagocytosis has been recognised as one of the important elements in the host's defense against invading micro-organisms [26]. Harikrishnan et al., [27] has reported that administration of 50 and $100 \mathrm{mg} / \mathrm{kg}$ doses of all triherbal TKM solvent extracts significantly enhanced phagocytic activity of leucocytes isolated from the olive flounder in $30 \mathrm{~d}$. Subeenabegum and navaraj [28] has observed percentage increase in the phagocytic activity of fish administered intraperitoneally with the plant extract is $32.36 \%$ in $S$. trilobatum, $35.2 \%$ in 0 . Sanctum and $96.05 \%$ in plant extract mixture compared with the control $68.4 \%$ increase was reported by Durgadevi and Balasubramanian [29] in C. carpio injected with the leaf extract of $S$. trilobatum. In the present study the phalocytic activity was siginificant enhanced in the common carp after administration of both medium and high doses of plant extract [30].

Lysozyme plays an important role in innate immunity by lysis of bacterial cell wall and thus stimulates the phagocytosis of bacteria. In this work the highest lysozyme activity was observed in group 3on $28^{\text {th }}$ day $1285 \pm 90.92$. In another study, among various doses of an aqueous extract of polygonum mines leaf, intraperitoneally injected into African catfish, Clarias gariepinus, only the dose of 15 $\mathrm{mg} / \mathrm{kg}$ BW of plant extract could significantly improve lysozyme activity $2 \mathrm{~d}$ post-treatment [31]. Fish lysozymes possess a high potential for bacteriocidal or bacteriolytic activity, anti-viral and anti-inflamatory properties and also play an important role in the bio-defense system against gram-positive and gram-negative bacteria [32]. In the jian carp, the lysozyme activity was observed on $20^{\text {th }}, 25^{\text {th }}$ and $30^{\text {th }}$ day after feeding [33].

In the present study the respiratory bust activity was found to be significantly higher in the treated groups compared to control $(\mathrm{p}<0.05)$ of this group3 showed a higher activity. Phagocytes produce toxic oxygen forms during a process called respiratory burst [34] since superoxide anion is the first product to be released from the respiratory burst, the measurement of $\mathrm{O}_{2}$ has been accepted as a precise way of measuring respiratory burst [35]. The present results showed that experimental fish treated with 0.30 $\mathrm{mg} / \mathrm{ml}$ doses of Stocheospermum marginatum showed enhanced respiratory burst after $28^{\text {th }}$ days. Janget al., [36] reported that in vitro treatment with glycyslizine enhanced the respiratory burst activity of macrophages and the proliferative responses of lymphocytes from rainbow trout. Similarly, in the present study the groups treated with Ulva lactuca also showed an improvement in the respiratory burst activity in the second week.

\section{CONCLUSION}

Collectively, it can be concluded that the ability of the Stocheospermum marginatum and Ulva lactuca to mediate nonspecific immune mechanisms is evident from the enhanced WBC, $\mathrm{RBC}, \mathrm{Hb}$ number and as well as elevated phagocytic, lysozyme and NBT activities. Due to its effectiveness seaweeds can be used as potential drug as an immunostimulant. However appropriate field trials are necessary before using them in aquaculture.

\section{ACKNOWLEDGMENT}

The authors are thankful to University Grants Commission (UGC), New Delhi for financial assistants and my Guide Dr. D. Radhika, Head, PG and Research Department Zoology, V. O. Chidambaram College, Thoothukudi for providing the necessary facilities, to carry out this work.

\section{FUNDING}

Nil

\section{AUTHORS CONTRIBUTIONS}

All the authors have contributed equally.

\section{CONFLICT OF INTERESTS}

Declared none

\section{REFERENCES}

1. Naylor R, Burke M. Aquaculture and ocean resources: raising tigers of the sea. Annu Rev Environ Resour. 2005;30(1):185218. doi: 10.1146/annurev.energy.30.081804.121034.

2. Khan MA, Khan S, Miyan K. Aquaculture as a food production system: a review. Biol Med. 2011;3:291-302.

3. Yu HB, Rao PSS, Lee HC, Vilches S, Merino S, Tomas JM, Leung KY. A type III secretion system is required for Aeromonas hydrophila $\mathrm{AH}-1$ pathogenesis. Infect Immun. 2004;72(3):1248-56. doi: 10.1128/IAI.72.3.1248-1256.2004, PMID 14977925.

4. Vivas J, Carracedo B, Riano J, Razquin BE, Lopez Fierro P, Acosta F, Naharro G, Villena AJ. Behavior of an Aeromonas hydrophila aro A live vaccine in water microcosms. Appl Environ Microbiol. 2004;70(5):2702-8. doi: 10.1128/AEM.70.5.2702-2708.2004, PMID 15128521.

5. Vasudeva Rao YV, Das BK, Jyotyrmayee P, Chakrabarti R. Effect of achyranthes aspera on the immunity and survival of Labeo rohita infected with Aeromonas hydrophila. Fish Shellfish Immunol. 2006;20(3):263-73. doi: 10.1016/j.fsi.2005.04.006, PMID 15961319.

6. Reverter M, Bontemps N, Lecchini D, Banaigs B, Sasal P. Use of plant extracts in fish aquaculture as an alternative to chemotherapy: current status and future perspectives. Aquaculture. 2014;433:50-61. doi: 10.1016/j.aquaculture. 2014.05.048.

7. Schwartsmann G, Brondani da Rocha A, Berlinck RG, Jimeno J. Marine organisms as a source of new anticancer agents. Lancet Oncol. 2001;2(4):221-5. doi: 10.1016/s1470-2045(00)002928. PMID 11905767.

8. Manilal A, Sujith S, Sabarathnam B, Kiran GS, Selvin J, Shakir C, Lipton AP. Bioactivity of the red algae asparagopsis taxiformis collected from the Southwestern coast of India. Braz J Oceanogr. 2010;58(2):93-100. doi: 10.1590/S167987592010000200002.

9. Patra J, Rath S, Jen K, Rathod V, Thatoi H. Evaluation of antioxidant and antimicrobial activity of seaweed (Sargassum sp.) extract: a study on inhibition of glutathione-S transferase activity. Turk J Biol. 2008;32:119-25.

10. Kolanjinathan K, Ganesh P, Govindarajan M. Antibacterial activity of ethanol extracts of seaweeds against fish bacterial pathogens. Eur Rev Med Pharmacol Sci. 2009;13(3):173-7. PMID 19673167.

11. Smit AJ. Medicinal and pharmaceutical uses of seaweed natural products: A review. J Appl Phycol. 2004;16(4):245-62. doi: 10.1023/B:JAPH.0000047783.36600.ef.

12. Newman DJ, Cragg GM, Snader KM. Natural products as sources of new drugs over the period 1981-2002. J Nat Prod. 2003;66(7):1022-37. doi: 10.1021/np030096l, PMID 12880330 . 
13. Abedin RMA, Taha HM. Antibacterial and antifungal activity of cyanobacteria and green microalgae evaluation of medium components by plackett-burman design for antimicrobial activity of Spirulina plastensis. Glob J Biotechnol Biochem. 2008;3(1):22-31.

14. El Gamal AA. Biological importance of marine algae. Saudi Pharm J. 2010;18(1):1-25. doi: 10.1016/j.jsps.2009.12.001, PMID 23960716.

15. Yin G, Jeney G, Racz T, Xu P, Jun X, Jeney Z. Effect of two Chinese herbs (Astragalus radix and Scutellaria radix) on non-specific immune response of tilapia, oreochromis niloticus. Aquaculture. 2006;253(1-4):39-47. doi: 10.1016/j.aquaculture.2005.06.038.

16. Yokoyama HO, Hasler AD, Bilstad NM. Studies on the origin, development, and seasonal variations in the blood cells of the perch, Perca flavescens [PhD thesis]. Anat Rec. 1947;99(4):680. PMID 18895478.

17. Christensen GM, Fiandt JT, Poeschl BA. Cells, proteins, and certain physical-chemical properties of brook trout (Salvelinus fontinalis) blood. J Fish Biology. 1978;12(1):51-60. doi: 10.1111/j.1095-8649.1978.tb04150.x.

18. Anderson DP, Siwicki AK. Basic haematology and serology for fish health programs; 1995. p. 185.

19. Magnadóttir B. Innate immunity of fish (overview). Fish Shellfish Immunol. 2006;20(2):137-51. doi: 10.1016/j.fsi.2004.09.006, PMID 15950491.

20. Sahu S, Das BK, Pradhan J, Mohapatra BC, Mishra BK, Sarangi N. Effect of Mangifera indica kernel as a feed additive on immunity and resistance to Aeromonas hydrophila in Labeo rohita fingerlings. Fish Shellfish Immunol. 2007;23(1):109-18. doi: 10.1016/j.fsi.2006.09.009. PMID 17161956.

21. Secombes CJ. The non-specific immune system: cellular defenses. In: Iwama G, Nakanishi T, editors. The fish immune system: organism, pathogen and environment. San Diego: Academic Press; 1996. p. 63-103.

22. Maqsood S, Singh P, Samoon MH, Munir K. Emerging role of immunostimulants in combating the disease outbreak in aquaculture. Int Aquat Res. 2011;3:147-63.

23. Yin G, Ardo L, Thompson KD, Adams A, Jeney Z, Jeney G. Chinese herbs (Astragalus radix and ganoderma lucidum) enhance immune response of carp, cyprinus carpio, and protection against aeromonas hydrophila. Fish Shellfish Immunol. 2009;26(1):140-5. doi: 10.1016/j.fsi.2008.08.015, PMID 18817878.

24. Manjrekar PN, Jolly CI, Narayanan S. Comparative studies of the immunomodulatory activity of Tinospora cordifolia and Tinospora sinensis. Fitoterapia. 2000;71(3):254-7. doi: 10.1016/s0367-326x(99)00167-7, PMID 10844163.
25. Mydeen KP, Haniffa MA. Evaluation of antibacterial activity of medicinal plants on fish pathogen Aeromonas hydrophila. J Res Biol. 2011;1:1-5.

26. MacArthur JI, Thomson AW, Fletcher TC. Aspects of leucocyte migration in the plaice, pleuronectes platessa L J Fish Biology. 1985;27(5):667-76. doi: 10.1111/j.1095-8649.1985.tb03211.x.

27. Harikrishnan R, Heo J, Balasundaram C, Kim MC, Kim JS, Han YJ Heo MS. Effect of traditional Korean medicinal (TKM) triherbal extract on the innate immune system and disease resistance in Paralichthys olivaceus against Uronema marinum. Vet Parasitol. 2010;170(1-2):1-7. doi: 10.1016/j.vetpar.2010.01.046, PMID 20207485.

28. Subeenabegum S, Navaraj PS. Studies on the immunostimulatory effect of extract of Solanum trilobatum and Ocimum sanctum in Mystuskeletius. Int J Fish Aquat Studies. 2016;4(2):376-81.

29. Durgadevi G, Balasubramanian V. Studies on the immunoprotective effect of Solanum trilobatum on the common carp Cyprinus carpio (L.). Proceeding of the conference on Recent Advances in Applied Zoology UGC and the management of ANJAC; 2009. p. 90-3.

30. Soltanian S, Fereidouni MS. Effect of henna (Lawsonia inermis) extract on the immunity and survival of common carp, Cyprinus carpio infected with Aeromonas hydrophila. Int Aquat Res. 2016;8(3):247-61. doi: 10.1007/s40071-016-0141-2.

31. Veerasamy R, Min LS, Mohanraj RP, Sivadasan S, Varghese C, Rajak H, Marimuthu K. Effect of aqueous extract of polygonum minus leaf on the immunity and survival of African catfish (Clarias gariepinus). J Coast Life Med. 2014;2(3):209-13.

32. Saurabh S, Sahoo PK. Lysozyme: an important defence molecule of fish innate immune system. Aquaculture Res. 2008;39(3):223-39. doi: 10.1111/j.1365-2109.2007.01883.x.

33. Jian J, Wu Z. Influences of traditional Chinese medicine on nonspecific immunity of Jian Carp (Cyprinus carpio var. Jian). Fish Shellfish Immunol. 2004;16(2):185-91. doi: 10.1016/S10504648(03)00062-7, PMID 15123322.

34. Neumann NF, Stafford JL, Barreda D, Ainsworth AJ, Belosevic M. Antimicrobial mechanisms of fish phagocytes and their role in host defense. Dev Comp Immunol. 2001;25(8-9):807-25. doi: 10.1016/s0145-305x(01)00037-4, PMID 11602197.

35. Secombes CJ, Olivier G. Furunculosis. New York: Academic Press; 1997. p. 269-96.

36. Jang SI, Marsden MJ, Kim YG, Choi MS, Secombes CJ. The effect of glycyrrhizin on rainbow trout, Oncorhynchus mykiss (Walbaum), leucocyte responses. J Fish Diseases. 1995;18(4):307-15. doi: 10.1111/j.1365-2761.1995.tb00307.x. 